\title{
Double outlet right ventricle
}

\author{
INSERM
}

\section{Source}

INSERM. (1999). Orphanet: an online rare disease and orphan drug data base. Double outlet right ventricle. ORPHA:3426

Double outlet right ventricle (DORV) is a rare cono-truncal anomaly in which both the aorta and pulmonary artery orig inate, either entirely or predominantly, from the morphologic right ventricle. 